\title{
Municipio y civismo. Las ordenanzas municipales como instrumento para la convivencia
}

\author{
Marisol Ibáñez Picó \\ Técnico de Administración General. Jefa de Sección de la Unidad de Disciplina Municipal \\ del Ayuntamiento de Leganés
}

Sumario: I. INTRODUCCIÓN. - II. EL CIVISMO COMO EXPRESIÓN SOCIAL DE DEMOCRACIA. 1. Concepto de civismo. El término «de moda». 2. Educación y cultura de convivencia como base del civismo.--III. ANÁLISIS DE LAS ORDENANZAS SOBRE CONVIVENCIA MÁS RELEVANTES DE LOS MUNICIPIOS ESPAÑOLES EN LA ACTUALIDAD. 1. Ayuntamiento de Madrid. 2. Ayuntamiento de Barcelona. 3. Ayuntamiento de Sevilla. 4. Ayuntamiento de Donostia-San Sebastián. 5. Ayuntamiento de Valladolid. 6. Ayuntamiento de PamplonaIruña. 7. Ayuntamiento de Mataró. 8. Ayuntamiento de las Palmas de Gran Canaria. 9. Ayuntamiento de Carmona. 10. Ayuntamiento de Irún. 11. Ayuntamiento de Leganés. 12. Ayuntamiento de Jirueque.-IV. LA SANCIÓN ADMINISTRATIVA COMO MEDIO DE SENSIBILIZACIÓN PARA CONDUCTAS CÍVICAS. 1. La potestad sancionadora local tras la Ley 57/2003, de 26 de diciembre, de medidas para la modernización del gobierno local. 2. Sanción administrativa y principio reeducador o concienciador. 3 . Otras actuaciones y medidas posibles en la instrucción del procedimiento administrativo.-V. CONCLUSIONES. - VI. BIBLIOGRAFÍA.

\section{INTRODUCCIÓN}

Sólo en A Coruña, Barcelona, Sevilla, Granada y Valladolid, el vandalismo urbano ocasiona un gasto anual que supera los 17 millones de euros. La Memoria de la Fiscalía General recoge que en 2004 fueron detenidos 6.757 menores por el delito de daños.

Según el último sondeo del Instituto de la Juventud, el siete por ciento de los jóvenes reconocía haber participado en algún tipo de gamberrada o destrozo. En Barcelona, el Ayuntamiento gasta un millón de euros mensuales en la reposición y reparación del mobiliario. En Valladolid, más de 1.000 jóvenes son denunciados en 2004 por orinar en la calle, y casi un centenar por destrozos en jardines y mobiliario. En Sevilla la organización del botellón generó ese mismo año 702.000 kilos de residuos.

¿A qué se debe y como actuar? ¿Se trata de gamberrismo organizado por rebeldes sociales?

A ello se une otro fenómeno al que últimamente están haciendo frente los Municipios: la nuevas situaciones provocadas por la convivencia entre gentes de diferentes culturas, idiomas y con problemas de adaptación.

Los gobiernos municipales deberán afrontar el reto de lograr la convivencia en la diversidad social. 
Sentimientos encontrados sobre logros sociales como la libertad y los derechos de los ciudadanos, chocan con una realidad en la que con una nostalgia mal entendida se reclaman valores ¿de antaño? ¿perdidos?

Y vemos como uno de los grandes pilares de las últimas campañas electorales (máximo ejemplo el de las últimas elecciones municipales) ha sido para la gran mayoría de partidos políticos la promesa de abordar ese tema, comprometiéndose a poner en marcha planes de actuación para resolver los problemas de convivencia o a la elaboración de una Ordenanza sobre civismo, si no contaban ya con ella.

Las Administraciones Locales han iniciado en los últimos años una serie de actuaciones dirigidas a abordar las nuevas demandas que exige el intenso cambio social de las ciudades, basadas en la participación Ciudadana, la integración y la educación en el respeto en las relaciones con el prójimo y con el entorno.

La necesidad de elaborar y aplicar sus propias normas de convivencia pública como máximo exponente y esencia del principio de autonomía local, nos lleva a la apuesta que han hecho la mayoría de Administraciones locales por las «Ordenanzas Municipales de convivencia».

Se trata de normas que tienden, en la mayoría de los casos, a integrar elementos muy heterogéneos en un único texto, cada una con sus particularidades, pero atendiendo a criterios e intereses muchas veces comunes.

\section{EL CIVISMO COMO EXPRESIÓN SOCIAL DE DEMOCRACIA}

\section{Concepto de civismo. El término «de moda»}

Para poder abordar el tema que nos ocupa es imprescindible detenernos en el significado de esa palabra que repetiremos una y otra vez mientras debatimos cómo y de qué forma lograr lo que expresa.

En cualquier caso, no puede olvidarse que se trata de un término muy utilizado últimamente, al entrar dentro de las palabras «bien sonantes» que agradan y producen consenso. Hasta el punto de que en la actualidad, en el momento en que los reclamos de marketing del sector bancario se orientan a la supresión de comisiones y acercamiento al usuario de clase media, una determinada entidad, en su afán de acercamiento y demostración de su interés por el cliente incluye en su campaña publicitaria el eslogan $« B A N C A C I ́ V I C A{ }^{1}$.

1 Campaña publicitaria de Caja Navarra (primavera-verano 2007) «BANCA CÍVICA» que da nombre a una iniciativa «la cuenta cívica» que consiste en llevar la iniciativa de la responsabilidad social a todos los 


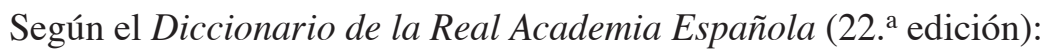

Civismo:

(del fr. Civisme)

1m. Celo por las instituciones e intereses de la patria

$2 \mathrm{~m}$. Comportamiento respetuosos del ciudadano con las normas de convivencia pública

¿Y qué significa, a su vez, «Convivir»? Pues convivir (del latín convivere) significa vivir en compañía de otro u otros.

Sin duda, de las dos acepciones de la palabra civismo, la primera que nos viene a la mente y que actualmente consideraríamos más adecuada, es aquella que lo relaciona con un comportamiento conforme a unas pautas sociales, que todos aceptamos como normas públicas de convivencia.

Pero esa definición, en la que estaríamos casi todos de acuerdo, encuentra precisamente el consenso pacífico en la amplitud de los términos que empleamos.

La misma palabra ciudad («cives»), avanza la importancia del marco político espacial, no son las casas las que hacen ciudad, son las personas cuando deciden organizarse para poder convivir quienes transforman un «territorio» en un «espacio público» y así se convierten en ciudadanos por el ejercicio de unos derechos y el cumplimiento de unos deberes.

Ya Aristóteles definía al hombre como «animal político» y a la sociedad como «Estado o ciudad». Afirmaba que los animales también tienen sociedad, viven juntos en grupo pero no tiene leyes, son agrupaciones poblacionales, su única ley es la naturaleza, no como el hombre que es él quien elige las leyes.

El poder público deberá definir un sistema legal que configure una estructura estable en la cual pueda vivir una sociedad y va a ser la autoridad municipal quien marque las normas más básicas que conformaran el orden social. Está claro que en nuestra sociedad las normas en las que se traducirán esas necesarias pautas de conducta serán la Constitución y el resto de Ordenamiento Jurídico vigente, en el marco de la expresión política que permitirá esa estructura: la democracia.

Pero la democracia como sistema no puede consistir en la simple adopción de decisiones por mayorías... pensemos en que los vecinos de un inmueble deciden libremente mediante votación y por unanimidad expulsar a un vecino

niveles de la sociedad, dejando a los clientes decidir qué proyectos apoyan y que conozcan hasta el céntimo la aportación de cada cliente al proyecto. Afirman una transparencia por la que se comprometen a decir a cada cliente cuánto ganan con él. 
porque es minusválido y les resulta costoso adaptar la finca a las necesidades de éste.

Así podremos observar en el momento en que pasemos a analizar las Ordenanzas vigentes sobre convivencia, lo difícil que es atender a esta realidad y cómo surgirán siempre problemas y conflictos por el choque de intereses.

\section{Educacion y cultura de convivencia como base del civismo}

Las exigencias de civismo se plantean en las circunstancias más cotidianas: reclamamos limpieza en las calles, silencio para el descanso, jardines cuidados.... y por ello frecuentemente esas manifestaciones y demandas de que sean todos los ciudadanos los que utilicen las papeleras, tengan cuidado con el volumen de la música, no destrocen las plantas... añorando esos principios por los que a nadie se le podía ocurrir hacer esas cosas!!

¿A qué principios o valores se hace referencia? ¿De qué «civismo esencial» se habla?

¿Cuántas veces no oiremos a alguien que reclama el regreso de esa asignatura escolar: ¡la urbanidad!

Sin duda es esa apelación a las buenas maneras se relaciona directamente con conductas adecuadas para una convivencia agradable y respetuosa basada en la idea de cuidado de lo público y respeto al resto de ciudadanos.

Dentro de esos mínimos de civismo que marca la urbanidad se incluyen como principios, conductas como ceder el asiento a nuestros mayores, ayudar a cruzar a los que lo necesiten... considerándose como antisociales aquellas que resultan inconvenientes para esa vida común en la ciudad.

No puede ponerse en duda que el civismo está ligado a la buena educación, VICTORIA CAMPS define la expresión buena educación en su libro «Virtudes Públicas» ${ }^{2}$ así: "decimos que una persona está bien educada cuando se comporta correctamente, conoce y practica las normas de cortesía al uso, no pierde la compostura y sabe estar en cualquier parte.»

Ocurre, no obstante que la realidad social que marca esas pautas básicas no es ni por asomo estática y única y lo que en un principio parecía definir todos los comportamientos demandados, debe revisarse a la vista de «nuevos valores».

2 Camps Cervera, V.,Virtudes Públicas, Premio Espasa Mañana de Ensayo 1990. 
Así si hoy quisiéramos volver a impartir esa asignatura por supuesto deberíamos revisar esas «Cartillas de urbanidad» que se utilizaban en las escuelas, distintas según el alumno fuese niño o niña ${ }^{3}$.
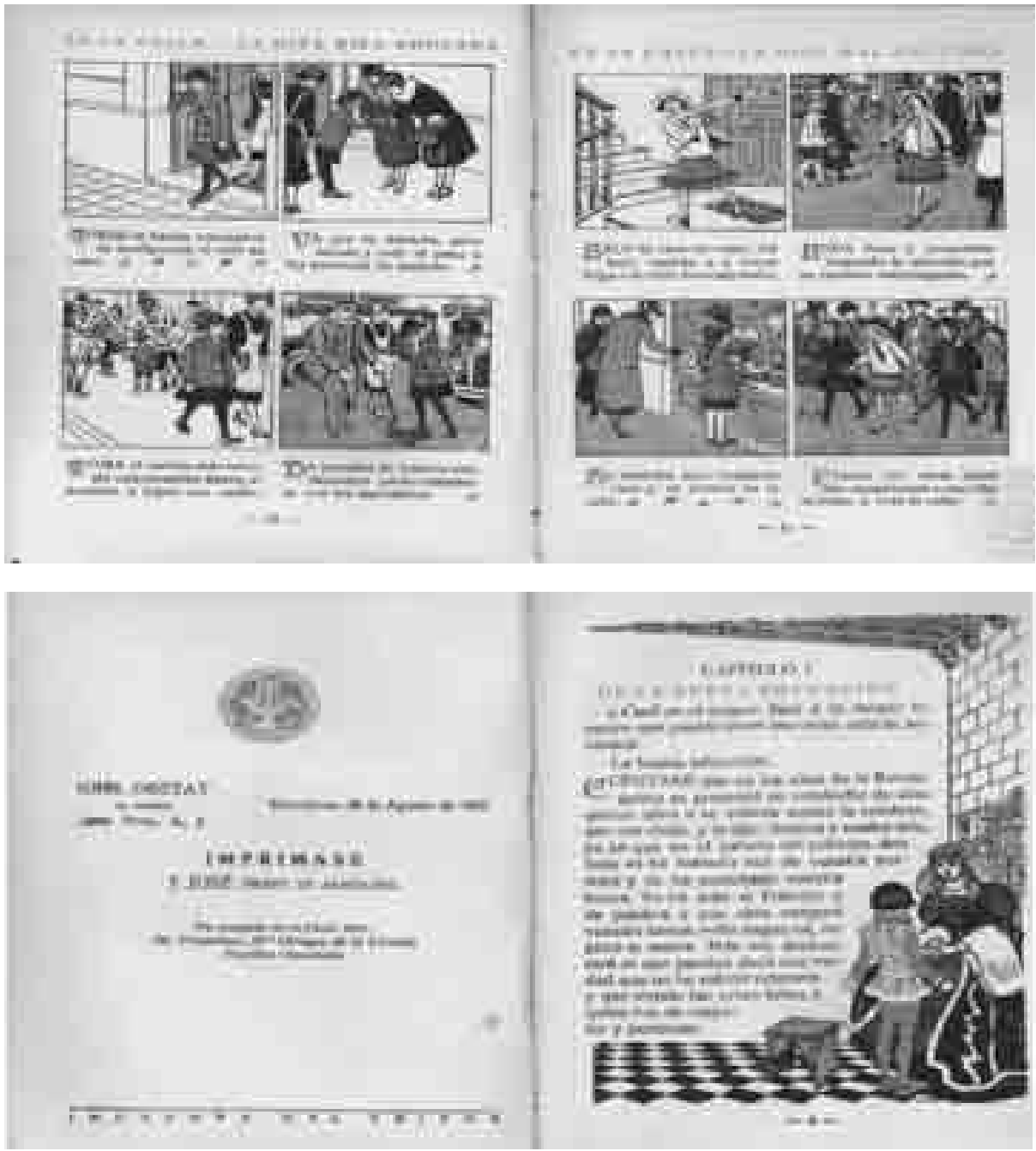

Estas indicaciones vistas hoy pueden parecernos carentes de sentido y en muchos casos contrarias a nuestros valores constitucionales. El contraste entre las sucesivas regulaciones jurídicas puede ser del todo revelador. Sin duda la foto de la niña sirviendo pacientemente en la mesa a sus hermanos varones, no tan sólo sería hoy impensable sino que ha sido sustituida por infinitas campañas para promover el reparto de las tareas domésticas....

3 Manuales de Formación Cívica y de Urbanidad 1931-1939. Cartilla moderna de urbanidad. Por F.T.D. 
Por ello, como veremos, el gran reto de los municipios en este tema viene marcado por la necesidad de adaptarse a esas nuevas realidades para conseguir los objetivos.

Basta ver el cambio físico de las ciudades, la existencia de mobiliario urbano, los estudiadísimos sistemas de depósito y recogida de la basura doméstica, de los excrementos caninos...

Todo responde a nuevas demandas de los ciudadanos ante nuevos valores.

El cuidado al medioambiente por ejemplo es, sin duda, un valor nuevo. Una exigencia innegable hoy que marca cualquier actuación pública y absolutamente desconocida e impensable para un municipio al que ya le suponía un gran reto lograr el abastecimiento de agua potable para su población.

Cualquiera de las actuaciones que realice el municipio, sea a través de pactos sociales, planes de actuación, consejos sectoriales... incluso la regulación a través de Ordenanza, implica tener en cuenta que el éxito pasa indiscutiblemente por la educación y prevención de conductas.

Comportamientos solidarios y para una convivencia pacífica requieren unos valores cívicos, tener educación significa aceptar unas reglas, reglas que facilitaran las relaciones en un espacio común.

Sin duda en este punto, debemos mencionar la nueva materia de Educación para la Ciudadanía y los Derechos humanos creada por la Ley Orgánica de Educación (LOE).

Así en el siglo XXI, ante la necesidad de considerar estas materias como objeto de estudio en la escuela sustituimos las «cartillas de urbanidad» por: tres bloques formativos para el currículo del tercer ciclo de Educación primaria. Individuos y relaciones interpersonales, convivencia y relaciones con el entorno y vivir en sociedad. Cuyos contenidos versarán sobre la libertad y la responsabilidad en la toma de decisiones, los derechos del niño, el reconocimiento y aprecio de las diferencias de género, la expresión y el control de las emociones, la identificación de rasgos de diversidad cultural y religiosa, principios de convivencia establecidos por la Constitución y hábitos cívicos, entre otros.

Al margen de la polémica suscitada los contenidos de esta asignatura, y el amplio rechazo que ha generado en determinados sectores de la sociedad, es absolutamente imprescindible apreciar la importancia que supone impartir una materia cuyos contenidos van a tener una triple dimensión de contenidos conceptuales, procedimentales y actitudinales.

Así, en este sentido, podemos acudir a la fábula moral a cerca de la condición humana que nos plantea William Golding en su libro «El Señor de las 
Moscas» ${ }^{4}$, donde hace una narración muy crítica con las construcciones educativas que se fundamentan solo en el uso de las medidas represivas.

Susceptible de lecturas diversas, para unos es la parábola que se estructura en torno a una treintena de muchachos solos en una isla desierta, que representa una ilustración de las tesis que sitúan la agresividad criminal entre los instintos básicos del hombre, y para otros constituye una requisitoria moral contra una educación represiva que no hace sino preparar futuras explosiones de barbarie cuando los controles se relajan.

Se trataría de la «manzana envenenada»: la libertad absoluta. La ausencia de unas normas, de unas pautas de comportamiento, de unos valores morales, genera una atmósfera opresiva que aumenta gradualmente a lo largo del relato hasta desbordarse en la locura más irracional que todos llevamos dentro.

Es innegable que convivir requiere aceptar unas reglas, mantener una moral solidaria mínima.

\section{ANÁLISIS DE LAS ORDENANZAS SOBRE CONVIVENCIA MÁS RELEVANTES DE LOS MUNICIPIOS ESPAÑOLES EN LA ACTUALIDAD}

Como ya apuntábamos en la introducción, el problema del vandalismo en la ciudad conlleva que pocos municipios se libren de de tener que dedicar gran parte de su presupuesto al mantenimiento y reposición del mobiliario urbano, impidiendo que se destine a fines tremendamente necesarios y que supondrían mejora de calidad de vida a los ciudadanos.

Sucede que el espacio urbano se desborda por la presión que supone albergar a un número cada vez más elevado de personas de tan distinta condición y origen. Según datos de la ONU, casi la mitad de la población mundial vive en las ciudades, en España el 70\% de los habitantes vive en los núcleos urbanos de más de 10.000 habitantes.

Ante esta situación, existe una demanda de la sociedad que se siente dañada a la autoridad local, como encargada del orden social, para que establezca y obligue a respetar esas normas que habremos marcado como pautas mínimas de conducta.

En el presente estudio vamos a centrarnos en el planteamiento de tres grandes ciudades como Madrid, Barcelona y Sevilla, y de otros municipios que han

\footnotetext{
4 Golding, W. El Señor de las moscas, 1954. Sinopsis: Un avión es derribado en tiempos de guerra estrellándose en una isla desierta. Sólo sobreviven los niños, de edades comprendidas entre los seis y los doce años. Éstos se ven forzados a una situación extrema que pondrá al límite su fuerza tanto moral como física. Las rígidas normas de conducta de un internado británico propias de una educación represiva dejan paso a lo peor de la condición humana.
} 
desarrollado otras Ordenanzas municipales sobre civismo que podemos considerar como más representativas en el panorama normativo actual, atendiendo también al marco global o plan de trabajo en el que la articulan.

Finalmente nos detendremos en una experiencia muy especial, la de un Ayuntamiento en régimen de Concejo Abierto: el Ayuntamiento de Jirueque, que nos ayudará a entender mejor las claves que determinarán las conclusiones de este estudio

\section{Ayuntamiento de Madrid (3.155.359 habitantes) ${ }^{5}$}

No encontramos una Ordenanza específica para el civismo, aunque debemos tener presente la todavía parcialmente vigente: Ordenanza Municipal de Policía Urbana y Gobierno de la Villa (BO AM 16/7/1948).

Pese a que su aplicación es casi nula, se trata sin duda de una norma curiosa, en cuanto a que no está totalmente derogada, y constituye un claro exponente de la concepción del «civismo-urbanidad» de la época en la que se elaboró: los años cuarenta.

Sirva de ejemplo el Contencioso-Administrativo ante el Tribunal Superior de Justicia de Madrid, interpuesto por un joven madrileño multado con 25.000 pesetas por orinar en la vía pública en aplicación de esta Ordenanza.

El caso, objeto de noticia en diferentes medios de comunicación ${ }^{6}$, sucedió cuando David, que en el momento de los hechos tenía 17 años, salía de un examen de selectividad en junio de 1996, cuando tuvo un apretón y detrás de un árbol consumó su necesidad fisiológica.

Una agente municipal le recriminó su acción y le denunció en base a esta Ordenanza Municipal por realizar «un acto indecoroso consistente en orinar.»

Tras el incidente, David recibió una carta de la Junta de Moncloa-Aravaca comunicándole que orinar en el Parque del Oeste estaba multado, al menos en su caso, con 25.000 pesetas.

Por medio de su progenitor, David recurrió explicando los motivos de la incontinencia del muchacho, en base a que estaba sometido en ese momento a tratamiento médico a base de diuréticos.

El caso, por supuesto, anecdótico, evidencia dos cuestiones que deben llamarnos la atención:

\footnotetext{
5 Fuente: FEMP.

6 Diario El Mundo, lunes 21 de septiembre 1998.
} 
Primero: lo problemático que resulta la aplicación de normas vigentes que resultan, cuanto menos obsoletas o muy disconformes con las realidades sociales, no sólo por el tipo de sanción o su cuantía, sino por el tipo de lenguaje empleado...

Segundo: que, al analizar algo más en detalle el fondo de este caso, la norma además de vigente sigue siendo necesaria y en ningún caso se cuestiona la conducta tipificada: está prohibido orinar en la vía pública, por ello el joven basa su defensa en la justificación.

Veremos como las nuevas Ordenanzas continúan tipificando la conducta descrita.

Nos referiremos a la Ordenanza Municipal de Policía Urbana y Gobierno de la Villa, aunque muy brevemente, por exceder de la materia objeto de este estudio, teniendo en cuenta que previsiblemente será pronto sustituida por una nueva Ordenanza de Civismo más acorde con la realidad social.

Contiene una regulación amplia, como es habitual en este tipo de Ordenanzas. Regula en catorce Títulos y uno adicional (690 artículos) temas que van desde la división territorial hasta el régimen de carnes, mantecas y embutidos, cadáveres enterramientos y exhumaciones, sobre serenos y caballerías, industria de la madera y depósito de leñas y carbones, tiro de pistola y carabinas, tiros de gallos, palomas y conejos...

Fiel reflejo del centralismo de la época y del «espíritu del Régimen» atiende a cuestiones socio-políticas de un momento de la historia de España.

Su lectura resulta cuanto menos curiosa. Sirva de ejemplo la prohibición de la blasfemia, de que existan en Madrid peluquerías mixtas o las condiciones que deben mantener las hosterias... (arts. 15, 32 y 592).

Las Ordenanzas sobre civismo actuales seguirán sometiendo la posibilidad del riego de las macetas a determinados horarios y condiciones que no molesten, y conductas como partir leña en las calles, serán sustituidas por la prohibición de mecanizar o lavar el vehículo...

La cría de gallinas en recinto urbano, por la prohibición de mantener animales domésticos en balcones...

El Ayuntamiento de Madrid, tratará los temas relacionados con la convivencia mediante la aplicación de otras ordenanzas municipales sectoriales más recientes, como puede ser la Ordenanza General sobre Medio Ambiente Urbano (BOCAM 31/10/85) que hace referencia a la adecuación de los comportamientos individuales que no deben alejarse de las relaciones de vecindad y principio de solidaridad social, describiéndose conductas como arrojar colillas, cáscaras, papeles, sacudir alfombras, propaganda... 
La Ordenanza Reguladora de la Tenencia y Protección de Animales del Ayuntamiento de Madrid (BOCM (31/8/2001) marca las pautas de inserción armoniosa de estos animales en la vida urbana, regulando el acceso a parques y jardines, limita el número de animales que pueden mantenerse en domicilios particulares...

La redacción está marcada por la voluntad de protección a estos animales y la búsqueda del respeto a los ciudadanos con los que conviven en la ciudad. Así por ejemplo, la redacción de los artículos 11.5 y 7 pretende ser un mecanismo que sirva para lograr la tranquilidad vecinal en el caso de animales en viviendas urbanas. Es innegable que muchos de los problemas en las relaciones de vecindad surgen por las molestias que causan animales de compañía cuyos amos no atienden a las exigencias de la vida en comunidad.

Puede observarse, que los contenidos de las nuevas Ordenanzas Municipales de los diversos temas sectoriales que se van redactando, se orientan a dar solución a estas cuestiones que constituyen uno de los mayores reclamos ciudadanos a la autoridad competente.

Los problemas que produce el consumo de bebidas en la vía pública de forma masiva, conocido como «botellón» dió lugar a la Ley autonómica 5/2002, de 27 de junio, sobre Drogodependencias y otros Trastornos Adictivos, por la cual queda prohibida la venta y consumo de bebidas alcohólicas en la vía pública, excepto en terrazas, veladores, ferias y fiestas patronales regulados por las Ordenanzas municipales correspondientes. Prohíbe, asimismo, la venta de bebidas alcohólicas en las gasolineras de la región durante las 24 horas del día, y obliga a los establecimientos, donde el consumo de alcohol no es «inmediato», a solicitar una segunda licencia municipal para venderlo, lo que está dirigido especialmente a restringir la venta nocturna de bebidas alcohólicas a menores en las llamadas «tiendas de chinos».

El Ayuntamiento de Madrid, acude a esta normativa autonómica, ante la ausencia de regulación propia, para dar respuesta a frecuentes problemas que estas conductas incívicas le ocasionan.

Por idéntico motivo, también, sin duda va a resultar muy útil a esta Administración Local, las medidas contenidas en el artículo 20 del Capítulo III del Proyecto de Ley 1/2007, de Medidas Urgentes de Modernización del Gobierno y la Administración de la Comunidad de Madrid, de Medidas para el embellecimiento, limpieza y calidad de vida de nuestras ciudades.

El Proyecto de Ley prohíbe realizar grafitis o pintadas en vía pública, monumentos, estatuas, arbolado o mobiliario urbano. Los ayuntamientos podrán ceder excepcionalmente espacios públicos para realizar murales y grafitis de valor artístico, siempre que no perjudiquen al entorno urbano. Las infracciones por estos incumplimientos podrán ser sancionados con hasta 6.000 euros de 
multa. No obstante, el infractor podrá sustituir la multa por la obligación personal de limpiar las pintadas de la vía pública. El proyecto de ley también recoge que los infractores podrán ser obligados a reparar los daños y perjuicios ocasionados con los grafitis o pintadas, así como a reparar las cosas a su estado anterior.

Como decíamos al principio, llama la atención que todavía no se haya acometido la labor de redactar una norma adecuada a la realidad de la convivencia ciudadana en la ciudad de Madrid, capaz de aglutinar la dispersión normativa actual. Con ello se lograría hacer más sencillo el trabajo a quien tiene el deber de velar por su cumplimiento y proporcionaría a los ciudadanos de Madrid la oportunidad de participar en crear un instrumento útil en la garantía de la convivencia, incluyendo los nuevos principios y planteamientos sobre el civismo urbano.

\section{Ayuntamiento de Barcelona (1.593.075 habitantes)}

Barcelona se ha caracterizado por ser una ciudad muy abierta a la participación Ciudadana desde hace tiempo (y así lo ha ido demostrando en los grandes eventos que ha celebrado en los últimos años, como Las Olimpiadas o el Forum de las Ciudades), lo cual ha ayudado enormemente a enfocar la normativa relativa al civismo desde un planteamiento de responsabilidad común entre Administración - Ciudadano.

No obstante, la elaboración de una Ordenanza específica sobre civismo es relativamente reciente, y apenas cuenta con un año de vigencia su «ORDENANZA DE MEDIDAS PARA FOMENTAR Y GARANTIZAR LA CONVIVENCIA CIUDADANA EN EL ESPACIO PÚBLICO DE BARCELONA» BOP de Barcelona, n. 20 anexo I, de 24 de enero de 2006.

Destaca, sobre todo, el conjunto de actuaciones previas a la redacción de la Ordenanza, que sobre estas materias ha ido llevando a cabo el Ayuntamiento, instando a la ciudadanía a la implicación activa de sus proyectos participativos.

Elaboró un Plan para la Promoción del Civismo, en la actualidad adscrito al Observatorio Permanente para la Convivencia, basado en la sensibilización y la participación ciudadana, que se ha consolidado en los diez distritos de la ciudad.

El Plan para la Promoción del Civismo, se marcó como objetivo a largo plazo el cambio de hábitos de la ciudadanía, basado en una conciencia mayor con respecto a los otros y al entorno y un sentimiento de responsabilidad y colaboración en la calidad de los espacios públicos.

Desde entonces, el Plan de Civismo ha desarrollado su estrategia de trabajo en torno a cuatro claves: la comunicación, el trabajo territorial, la generación de 
recursos cívicos para la sensibilización y el trabajo con el voluntariado y la participación ciudadana.

Su modelo participativo se estructura en base a una figura ambiciosa y fundamental, en un proceso que pretende ir mucho más allá de una campaña publicitaria, una página web y una norma positiva con la que imponer sanciones administrativas: la Comisión Cívica. La Comisión Cívica es un consejo consultivo que asesora y que quiere ser el altavoz de las propuestas municipales que se formulen para promover el civismo en la ciudad. Empezó a funcionar el 21 de noviembre de 2003.

Se compone por representantes de diferentes sectores de la ciudad, personalidades de ámbitos como el deporte, la cultura o la educación que tratan de buscar la concepción que los ciudadanos sienten sobre la convivencia y los valores del civismo urbano.

Hacer sentir el civismo protagonista en la vida urbana, es sin duda una de las pretensiones de otra novedosa iniciativa del Ayuntamiento: la puesta en marcha del teléfono del civismo.

A través de un número gratuito: 900226226, los ciudadanos pueden comunicar incidencias, reclamaciones, avisos o sugerencias sobre la ciudad y los servicios municipales.

El 010 municipal concentra ahora únicamente los servicios de información y tramitación administrativa y este nuevo servicio amplía el horario de 8 a 22 horas de forma ininterrumpida laborables y festivos.

La Ordenanza se compone de 102 artículos y prevé una revisión de sus contenidos cada dos años, con el fin de continuar unida a la realidad social que pretende regular.

Se prohíbe ensuciar, manchar o deslucir el entorno urbano de cualquier otro modo. Realizar grafitis o pintadas se considera una infracción leve. Hacerlo en elementos de transporte, de parques y jardines públicos, fachadas de edificios y señales de tráfico, como también en el mobiliario urbano, es una infracción grave, y pintarlos en monumentos y edificios catalogados o protegidos es una infracción muy grave. Siempre que sea posible, se conminará a las personas responsables de los grafitis o pintadas a borrarlos.

La ordenanza prohíbe utilizar a menores de edad o a personas con discapacidades como reclamo para pedir limosna y exigir ejercer prestaciones de servicios no solicitados, como por ejemplo la acción de los «limpiaparabrisas» en los semáforos.

Considera los comportamientos discriminatorios o de contenido xenófobo, racista o sexista, como infracciones graves. Los dirigidos contra personas ma- 
yores, menores y personas con discapacidades o actitudes de acoso a menores realizados por grupos, como bandas juveniles, están consideradas infracciones muy graves.

En los casos de utilización del espacio público para el ofrecimiento y demanda de servicios sexuales a 200 metros de centros docentes o educativos y cuando excluyan o limiten otros usos, los agentes de la autoridad o los servicios municipales recordarán a las personas que las practiquen que aquella actividad no está permitida y que tienen a su alcance programas de asistencia social.

El Ayuntamiento de Barcelona prepara un plan para el abordaje integral del trabajo sexual, con el objetivo de evitar que el ejercicio de la prostitución en el espacio público afecte a la convivencia ciudadana.

Las apuestas son consideradas infracción grave. Los juegos detrile son considerados infracciones muy graves.

Como «uso impropio del espacio público», la Ordenanza incluye las conductas que de manera intencionada perturban la tranquilidad de las personas y, en especial, el uso inadecuado del mobiliario urbano y del espacio público en general. Por ejemplo, no se permite dormir, ya sea de día o de noche, en los bancos para sentarse. Cuando se trate de personas con problemas de exclusión social no se aplicarán las sanciones, sino que intervendrán los servicios de atención social para su asistencia.

Se prohíbe el consumo de bebidas alcohólicas en espacios públicos que puedan causar molestias en su entorno y en envases de cristal o de lata fuera de terrazas, veladores y espacios habilitados para hacerlo. Según las características del consumo de bebidas alcohólicas, esta práctica puede ser considerada una infracción leve, o bien una infracción grave.

La Ordenanza no insiste sólo en la prohibición de la venta ilegal de cualquier tipo de producto en el espacio público, sino que también sanciona a los compradores y las personas que colaboran con los vendedores, por ejemplo alertándolos de la presencia de agentes de la autoridad. Comprar un CD o un DVD piratas en un «top manta» o una lata de bebida a un vendedor ilegal ambulante está considerado una infracción leve. La misma sanción reciben las personas responsables y colaboradoras de la venta ambulante.

Estropear el mobiliario urbano puede ser considerado, por su gravedad, una infracción grave o muy grave.

También regula la prestación de todo tipo de servicios no autorizados en plazas y calles, como el de videntes, tarot y realización de masajes o tatuajes en el espacio público. 


\section{Ayuntamiento de Sevilla (704.154 habitantes)}

Sevilla cuenta con la «ORDENANZA MUNICIPAL DE MEDIDAS PARA EL FOMENTO Y GARANTÍA DE LA CONVIVENCIA CIUDADANA EN LOS ESPACIOS PÚBLICOS DE SEVILLA» aprobada inicialmente en Pleno de fecha 15 de marzo de 2007. En el BOP de Sevilla de 18 de abril se publica dicha aprobación inicial.

En la actualidad no se ha producido la aprobación definitiva y preceptiva publicación en el Boletín Oficial, por lo que no ha entrado en vigor.

Su publicación parece condicionada, no sólo al estudio de las alegaciones que se han presentado, sino también a la orientación o tratamiento que tenga por conveniente la nueva Corporación Municipal.

Tras las recientes elecciones, el Ayuntamiento ha experimentado una serie de cambios, entre los cuales está el nuevo nombre y posiblemente diferente estructura del Área de Gobernación, lugar en el que gestó (hoy Delegación de Convivencia y Seguridad).

Al tratarse de una norma no vigente, no vamos a realizar un análisis pormenorizado, máxime cuando existen perspectiva de una posible reforma e incluso replanteamiento de la regulación, por lo que nos limitaremos a revisar brevemente el texto aprobado inicialmente.

Consta de 50 artículos y se la conoce como la «Ordenanza antivandalismo» pretendiendo dar respuesta a un agobiante problema de actuaciones incívicas en Municipio.

Se rige por un doble principio: el de la prevención y el de que «quién la hace la paga», con multas de hasta 30.050 euros y actividades reeducativas y tareas de resocialización para menores.

Llama la atención el resto de medidas que incluye en su articulado y que se orientan hacia el fomento de de actividades de colaboración y cooperación social hacia los valores de convivencia y civismo en la ciudad.

Medidas como: La elaboración anual de un Plan Cívico de Sevilla, convocatoria de Premios Municipales al Civismo ciudadano, la creación de una unidad policial específica de 50 agentes que velarán por el cumplimiento de la nueva ordenanza.

Se sancionan conductas que causen menosprecio a la dignidad de las personas, como el comportamiento discriminatorio y los insultos machistas o xenófobos, la mendicidad coactiva ejercida por los «gorrillas», o el uso indebido de artefactos pirotécnicos. 


\section{Ayuntamiento de Donostia-San Sebastián (182.930 habitantes)}

Cuenta con la «ORDENANZA SOBRE EL CIVISMO, REGULADORA DEL USO Y LA LIMPIEZA DE LA VÍA PÚBLICA Y LA PROTECCIÓN DEL ARBOLADO «Aprobada en Pleno de 31/8/04, se publica en el BOG de 22/9/04 y su entrada en vigor tiene lugar el 10/9/04. Consta de 54 artículos.

La unidad responsable de su aplicación es la Dirección de Mantenimiento y servicios Urbanos del Ayuntamiento, incluyéndose entre las Ordenanzas de Mantenimiento y Servicios.

A través de la Delegación de Participación Ciudadana, y con la colaboración de distintos Departamentos, viene impulsando desde hace años dinámicas de participación, consulta y debate que buscan incorporar la opinión ciudadana en los procesos de toma de decisiones en la gestión municipal, se articulan diferentes actuaciones para el fomento del civismo y la participación. En Sesión Plenaria de 24 de julio de 2007 se aprobó el nuevo Reglamento de Participación Ciudadana, que pretende un texto que detalla un catálogo de derechos del ciudadano, regula cómo se deben atender sus reclamaciones o su participación en los consejos, comisiones y Pleno, y crea nuevas figuras como la Defensoría Vecinal, los talleres de debate y las listas de personas interesadas en áreas concretas. El nuevo Reglamento, tiene su base en el Plan Director de Participación y pretende lograr la colaboración activa de los ciudadanos en todas las esferas de la gestión municipal.

\section{Ayuntamiento de Valladolid (321.001 habitantes)}

Cuenta con la «ORDENANZA MUNICIPAL SOBRE PROTECCIÓN DE LA CONVIVENCIA CIUDADANA Y PREVENCIÓN DE ACTUACIONES ANTISOCIALES». Aprobada inicialmente en Pleno de 14 de enero de 2004, con aprobación definitiva de fecha 13 de abril y publicación en el BOP de 14 de junio de 2004. Consta de 31 artículos.

El Ayuntamiento ha puesto en práctica diferentes actuaciones, promocionando el asociacionismo y la participación ciudadana.

Se fomenta el uso por los ciudadanos de los Centros cívicos, los consejos de Centros que celebran reuniones periódicas (cuatrimestrales) para canalizar iniciativas de mejora individuales o colectivas de los ciudadanos.

La «Ordenanza Municipal sobre Protección de la Convivencia Ciudadana y Prevención de Actuaciones Antisociales», tuvo bastante oposición ciudadana desde el inicio de su redacción, llevando a diferentes entidades y asociaciones a manifestarse en contra de la misma.

En cualquier caso, no debemos pasar por alto el carácter altamente «de respuesta o instrumento de disuasión» que presenta esta Ordenanza municipal, enfocada exclusivamente al «antivandalismo». 
De su lectura se infiere este carácter, muy distinto al pretendido por la mayoría de las nuevas normas de este tipo que buscan planteamientos más globales y participativos en búsqueda de formulas de convivencia.

Así su texto utiliza una redacción demasiado imperativa, atendiendo a los deberes sin contraponer el derecho que se pretende proteger. Parece incluir modelos de conductas, obligaciones y prohibiciones, términos que deben ser usados con cautelas para no proyectar connotaciones represivas que conllevan el efecto contrario al deseado: la reacción social de rechazo a la norma.

Regula temas de pintadas, daños varios a mobiliario urbano, colocación de carteles, adhesivos y elementos similares, mantenimiento de jardines y parques, vertido de residuos y basuras, lavado de automóviles en vía pública...

LLama la atención la previsión en su artículo 31 de una posible «Terminación convencional» que sin más desarrollo que el contenido en ese artículo es imposible llevarlo a la práctica, quedando así en una intención, pero que en realidad es puro «papel mojado».

Como la regulación de los olores y los ruidos vecinales, que por la imposibilidad de medición de los COVS (compuestos orgánicos volátiles) para el Municipio, va a quedarse también en una mera recomendación, pues el mal olor no deja de ser sino subjetivo, cuando no «discutible» determinarlo y demostrarlo ante un Tribunal.

El consenso no se logró tampoco tras su entrada en vigor e incluso llevó a la interposición de algunos recursos contra la misma, prosperando como veremos dos de ellos y dando lugar a dos Sentencias de la Sala de lo Contencioso Administrativo del Tribunal Superior de Castilla y León del año 2006 (Sentencia 2169 de 5 de diciembre, por la que se declaran nulos los artículos 20.1,20.2,23 g y 28.1 y Sentencia 2247 de 15 de diciembre por la que se declaran nulos los artículos 20.2, 23a), 24a) y 28.1 de la Ordenanza Municipal).

Los motivos de anulación y las argumentaciones del Tribunal resultan muy interesantes, tanto en la estimación de anulación de algunos artículos como en la desestimación de anulación total de la Ordenanza que se solicitaba, por lo que es conveniente que nos detengamos, aunque brevemente en algunas de las argumentaciones contenidas en la primera de las Sentencias citadas, que resuelve un recurso presentado por la Federación de asociaciones de vecinos y consumidores de Valladolid Antonio Machado.

Así se desestima la impugnación de nulidad total de la Ordenanza por no tener carácter residual que se estima deriva de la regulación que por la Ley 57/2003, se hizo de en la Ley de Régimen Jurídico de las Administraciones Públicas y del Procedimiento Administrativo Común y en la Ley Reguladora de Bases de Régimen Local.

En su Fundamento de Derecho III afirma que « la Ley 57/2003 ha venido a llenar un vacío legal y permitido que se legisle reglamentariamente donde antes 
no se podía hacer: se pasa así de una interpretación restringida de la ley a una interpretación armónica del sistema de competencias municipales.»

El Tribunal estima la anulación parcial y anula los preceptos de la ordenanza de prevención de acciones vandálicas referidas a:

1. La responsabilidad directa de las entidades convocantes de un acto público por los daños o suciedad derivados de los asistentes.

2. Obligación de prestar fianza previa para cubrir los gastos de limpieza a reposiciones de las entidades convocantes de un acto.

3. Responsabilidad directa de los padres por los incumplimientos a la ordenanza de sus hijos menores de edad.

Asimismo restringe al ámbito mercantil y no al de la libertad de expresión la aplicación del artículo referido a la pegada de información o carteles en lugares habilitados para ello.

\section{Ayuntamiento de Pamplona-Iruña (193.328 habitantes)}

En Pleno del Ayuntamiento de Pamplona, en Sesión celebrada el 20 de diciembre de 2005, se aprobó inicialmente la «ORDENANZA MUNICIPAL SOBRE PROMOCIÓN DE CONDUCTAS CÍVICAS Y PROTECCIÓN DE LOS ESPACIOS PÚBLICOS». Publicado el Acuerdo de aprobación en el BO de Navarra n. ${ }^{\circ} 15$, de fecha 3 de febrero de 2006, y transcurrido el plazo de exposición pública sin que se produjesen alegaciones, la aprobación definitiva de dicha Ordenanza se publica en el BOP n. ${ }^{\circ} 61$ de fecha 22/5/2006.

La Ordenanza se enmarca en un contexto de actuaciones de fomento de la participación ciudadana y búsqueda de consenso en comportamientos de convivencia.

Previa a su redacción fue la «CARTA DE DERECHOS Y DEBERES DE LOS CIUDANOS DE PAMPLONA ANTE SU ADMINISTRACIÓN MUNICIPAL».

Se trata de un documento algo distinto a las más usuales cartas de servicios que elaboran actualmente los Municipios, y va más allá, contemplando desde una perspectiva más global la necesaria relación entre los dos agentes: Administración-Ciudadanos. Veremos como a modo de catálogo de Derechos y Deberes, si ha sido contemplada de forma expresa en el propio texto normativo por algunas de las más recientes Ordenanzas como por ejemplo la de Barcelona.

La Ordenanza, de 41 artículos, va más allá del tema antivandálico y pretende buscar la colaboración e implicación ciudadana.

Ahora, bien, la norma, no exenta de polémica, ha sido duramente criticada por la oposición municipal y algunos colectivos locales que, al menos en 
sus primeras redacciones, veían en ella un «instrumento represor más del Ayuntamiento».

El texto final es una compilación de otras ordenanzas municipales, pero recoge también nuevas normativas, todas ellas tendentes a fomentar las conductas y los valores cívicos y buscar la protección de los bienes públicos mediante un régimen de sanciones.

Destaca la oferta del Ayuntamiento de la sustitución total o parcial de la sanción de multa que pudiera imponerse por la realización de tareas o labores similares y proporcionados a la gravedad, evitándose en parte la sanción económica.

\section{Ayuntamiento de Mataró (116.698 habitantes)}

La ciudad de Mataró cuenta desde el año 2005 con la «ORDENANZA DE CIVISMO DE MATARÓ» (BOP 2 de febrero de 2005, n. ํ2, Anexo).

Dicha Ordenanza se gestó en el área de vía pública, pero tanto en su elaboración como en su aplicación interviene de forma determinante Participación Ciudadana.

Se compagina con otras actuaciones importantes en materia de civismo como es la figura del Consell de Ciutat o el Defensor del Vecino, el teléfono 010...

El Consejo de Ciudad se constituye por primera vez el 7 de mayo de 2005 con el objetivo de debatir y consensuar las grandes líneas estratégicas de la ciudad.

Pero es la Ordenanza de Civismo la gran estrella en la búsqueda de la convivencia urbana.

Partiendo del consenso del pacto político gobernante en la ciudad, pronto se convirtió en una norma bien acogida por la ciudadanía y ambiciosa tanto en su regulación como en la apuesta por las medidas alternativas que prevé.

Mataró también se incluye entre los Municipios que optan por la reeducación y sustitución de la sanción pecuniaria, pero ellos lo articulan legalmente para darle contenido real.

Por ello, se incorpora a la Ordenanza, como Anexo I, un cuadro de sanciones y conmutaciones a las mismas y como Anexo II LA INSTRUCCIÓN GENERAL DEL SISTEMA DE PRESTACIÓN SUSTITUTIVA A LAS INFRACCIONES DE CIVISMO que incluye la relación de las entidades y órganos públicos donde se llevarán a término las actividades alternativas a la sanción económica y actividades supletorias.

La Ordenanza, consta de 29 artículos. Muy debatida entre los grupos políticos pese a publicarse y entrar en vigor en el año 2005, fue redactada con bas- 
tante antelación y no se adaptó a la Ley 57/2003, como puede observarse, fundamentalmente, en la regulación de las sanciones.

\section{Ayuntamiento de las Palmas de Gran Canaria (378.628 habitantes)}

Desde el año 1998, disponen de su «ORDENANZA DE CONVIVENCIA CIUDADANA Y VÍA PÚBLICA» (BOP 19/1/1998). Consta de 97 artículos.

Se trata de una de las primeras normas de estas características llevadas a término por los Ayuntamientos, por lo que en ella podemos observar además de, por supuesto su no adaptación a las recientes pautas y criterios de la Ley $57 / 2003$, un distanciamiento de los objetivos en la sanción ahora pretendidos en casi la totalidad de normas de este tipo. No obstante, parece inminente una revisión de la Ordenanza en este sentido.

Es una norma aplicada sin problemas por el Ayuntamiento, que la complementa con la Ley de la Comunidad 9/98 sobre «el botellón », para ese otro tipo de conductas ahora tan problemáticas.

La conciencia social de su aplicación es determinante, como expresan los técnicos responsables del Municipio «se sabe lo que hay». Así es frecuente imponer sanciones de $120 €$ por lavar los coches en la calle, perturbar en la vía pública...

\section{Ayuntamiento de Carmona (26926 habitantes)}

$\mathrm{Su} » O R D E N A N Z A$ DEL CIVISMO Y LA CONVIVENCIA» (BOP n. 70, 26 de marzo de 2002), fue de las primeras que se redactaron sobre este tema y una de las que más se dio a conocer, teniendo en cuenta el número de habitantes del municipio y sus recursos (de hecho, hasta hace poco era el único texto de referencia en la misma FEMP).

$\mathrm{Su}$ contenido es menos novedoso hoy, sobre todo tras el nuevo ámbito abierto por la ley 57/2003, pero en su momento fue el referente municipal por excelencia.

Consta de 85 artículos.

Pese al carácter ambicioso de la iniciativa de su redacción, se trata de una norma sin apenas aplicación práctica.

La falta de medios en el municipio, unida a una descoordinación con la Policía Local, son las causas que exponen los responsables municipales, cuando afirman que «como mucho se tramitan 2 ó 3 expedientes al año y nunca se han puesto en práctica medidas distintas a la sanción pecuniaria, pese a lo previsto en la Ordenanza». 


\section{Ayuntamiento de Irún (59508 habitantes)}

Irún cuenta con la «ORDENANZA MUNICIPAL SOBRE COMPORTAMIENTO CÍVICO Y REGULADORA DEL USO, OCUPACIÓN Y LIMPIEZA DE LA VÍA PÚBLICA» BO de Guipúzcoa, n. ${ }^{\circ}$ 133, de 14 de julio de 2005. Consta de 66 artículos.

La Ordenanza se redactó con un amplio debate previo, buscando colaboración e intervención de la ciudadanía y con un trabajo de sondeos de opinión y la elaboración de una encuesta en cuyos resultados se basarían los ejes de actuación.

Recientemente se ha llevado a cabo el programa «Irun por el Civismo/Irún Gizalegez». Una de las líneas de actuación de este proyecto es la presencia en la calle de los agentes cívicos. Desde la calle reciben comentarios ciudadanos; actúan directamente «in situ» dando avisos a ciudadanos por acciones incívicas, y en general, refuerzan las actuaciones del programa por el civismo puesto en marcha.

Según responsables municipales, el razonable éxito que afirman existe en su aplicación, se basa en que «primero se da ejemplo y se ponen medios y luego se exige».

\section{Ayuntamiento de Leganés (181.248 habitantes)}

El Municipio de Leganés cuenta con la ORDENANZA MUNICIPAL SOBRE EL CIVISMO Y LA CONVIVENCIA CIUDADANA, aprobada en Pleno de 9 de mayo, BOCM 15 septiembre de 2006.

El Ayuntamiento ha puesto en marcha diversas iniciativas dirigidas al fomento de la participación ciudadana.

Con el Plan «Leganés por el Civismo» se pretende lograr la participación de los ciudadanos de Leganés, con el objetivo fundamental de contribuir a cambiar a la idea de que «lo público no es de nadie» por la de «lo público es de todos y entre todos tenemos que cuidarlo».

De acuerdo con lo dispuesto el Reglamento de Participación Municipal, se contemplan los Consejos Sectoriales, compuestos por representantes del Gobierno Municipal, de las entidades que forman parte de los mismos y también por técnicos municipales. Los Consejos Sectoriales se configuran como órganos de participación, información, propuestas y seguimiento de la política y gestión municipales en relación con los diferentes sectores de actuación. En definitiva, se trata de órganos de carácter consultivo de las decisiones municipales.

Pionera sin duda, fue la decisión de este Ayuntamiento del sur de Madrid que creo un museo del grafiti. 
La Ordenanza consta de 53 artículos. Incluye definiciones de interés, aclarando conceptos, junto con una exposición ejemplificativa de cuales son los derechos y deberes en el marco de la convivencia pública de los ciudadanos así como el comportamiento de los servicios municipales y agentes de la autoridad.

Regula el tema de pintadas y grafitos, contemplando supuestos que no se recogían encaje en la normativa anterior.

Prevé la posibilidad de que el Ayuntamiento actúe previamente y luego impute el coste además de la sanción.

El objetivo fundamental es procurar un regulación sobre el tema que logre evitar tanto la suciedad tanto en el paisaje urbano, como en nuestros propios portales.

En cuanto a la publicidad, se busca dar la posibilidad al ciudadano de que determine si quiere o no recibirla, el Ayuntamiento no puede prohibirla en lugares privados, pero les da la opción a que ellos si lo hagan y en ese caso sería sancionable.

El Ayuntamiento distribuye gratuitamente unos carteles del modelo oficial que tendrá validez (objetivo: estético y legal - se obtiene con el acuerdo de los vecinos...-).

Novedoso es también el tema de prohibir a nivel del Municipio el tema de la publicidad que atente a valores esenciales de la persona.

En la regulación referente a jardines, parques, arbolado viario y otras zonas verdes, se hace especial énfasis en la necesaria colaboración ciudadana con los trabajadores municipales, con una protección muy especial a los parques infantiles, intentando concienciar de la necesidad del buen uso.

Resulta tremendamente útil y responde a una demanda social, la prohibición de los ruidos molestos para la convivencia ciudadana. Se marca un horario de obligado respeto al descanso. Se trata de buscar unas pautas de respeto vecinal. Las autoridades intervendrán buscando siempre el compromiso y respeto entre vecinos.

No se regulan los olores molestos, como han hecho otros municipios, según los responsables municipales «por lo utópico de la medida», ya que es muy difícil controlar los COVS (compuestos orgánicos volátiles), no ocurre igual con el ruido para el que se dispone de un sonómetro...

Se efectúa una clasificación de las sanciones acorde con lo dispuesto en la Ley 57/2003 de Medidas de Modernización del Gobierno Local y contemplando las prescripciones que esta Ley establece para las infracciones.

Se detalla el tema de la responsabilidad. 
Importantes son las previsiones contenidas en su artículo 48, según el cual cuando el infractor sea un menor de edad se abrirá un período de información previa para coordinar con la Delegación de Servicios Sociales las posibles medidas a adoptar, e incluso en supuestos excepcionales por su problemática, la conveniencia o no de iniciar el procedimiento sancionador.

Se contempla la posibilidad de pago voluntario para cerrar el procedimiento, así como de bonificación abonarse la propuesta económica de sanción antes del plazo previsto para la presentación de alegaciones.

Debe reponerse el bien a su estado originario, independientemente de la sanción.

Pero lo más importante, es destacar la estrecha y valiosísima colaboración y trabajo en equipo que llevan a cabo las distintas áreas municipales, obligadas por las previsiones de la Ordenanza a un trabajo conjunto en la tramitación de los expedientes.

Procedimiento de terminación y trabajos voluntarios alternativos a las sanciones y una apuesta auténtica por lograr los objetivos que se pretenden con la ordenanza y demás actuaciones por el civismo.

En la actualidad cualquier norma de estas características debía incluir un régimen alternativo para encajar con los nuevos planteamientos del Derecho Administrativo Penal.

No obstante, se puede comprobar como la mayoría de las Ordenanzas simplemente enuncian el tema, sin articularlo, o a veces incluso son tan «confiadas» que dejan en manos del interesado el determinar si quiere llevar a cabo alguna prestación... en definitiva, se expone la medida pero resulta imposible llevarla a cabo...

La idea ha sido, según los responsables municipales «no regular nada que no sea factible poner en práctica». Se ha pensado que es interesante el desarrollo concreto del tema a través de un Decreto: en el «PROGRAMA DE MEDIDAS ALTERNATIVAS A LA SANCIÓN PARA LA REEDUCACIÓN CÍVICA» que desarrolla el Título VI de la Ordenanza. Así es mucho más operativo en caso de cambios y se aprobó mediante Decreto de Alcaldía de fecha 6 de noviembre de 2006.

\section{Ayuntamiento de Jirueque (78 habitantes)}

\section{Comunidad Autónoma: CASTILLA-LA MANCHA}

Provincia: GUADALAJARA

Pieza clave para este estudio, va a resultarnos el detenernos en el caso de el pueblo de Jirueque, municipio de muy escaso censo, donde vivir en comunidad 
puede y debe disfrutarse en su esencia más pura: la plena participación a través del concejo abierto.

Tal vez contemplar como se defienden y articulan las esenciales normas de urbanidad fuera de la urbe, en un entorno eminentemente rural, a través del quehacer diario y permanente de todos y cada uno de sus vecinos, nos ayude mucho a reflexionar.

Jirueque aprobó ya en el año 2002, en Asamblea Vecinal la redacción de su «ORDENANZA DE CONVIVENCIA CIUDADANA» publicada en el BOP n. ${ }^{\circ} 64$ de 29 de mayo.

Antes de detenernos en los contenidos específicos de dicha norma, es preciso, pues ahí radica su mayor importancia y relevancia para este estudio, adentrarnos un poco en la realidad de este pequeño municipio español, dedicado a la agricultura.

Se trata de un pueblo que goza del régimen de Concejo Abierto.

Se integra, en la actualidad por unos 80 vecinos. Por supuesto, no tienen policía y acuden cuando les es preciso a la Guardía Civil.

Cuentan con 79 concejales, un gran número, pero que poco pueden colaborar por estar dedicados en su mayoría a las duras tareas agrícolas; con un Secretario que acude una vez a la semana y apenas puede revisar algún tema y hacer las certificaciones...

Su Alcalde compagina el cargo con la profesión de labrador, y es el amable y entrañable Sr. Virgilio, quien con muchísima voluntad, aúna tareas de Primer Teniente Alcalde, Alcalde en funciones casi la totalidad del año, fontanero, electricista, Secretario, contable... A él hay que acudir para que nos ayude a comprender cómo un grupo tan reducido de personas ha decidido obligarse a través de una norma para seguir una serie de pautas de convivencia contenidas en 26 artículos.

En un ámbito eminentemente rural, de momento no invadido por demasiados excursionista o domingueros, ... con una población tan escasa..... ¿Por qué se ha redactado una ordenanza municipal para la convivencia?

Y decíamos que este supuesto es determinante para entender razones y caminos a seguir, pues en principio nos aleja de las motivos o problemas por los que la «urbe» acude a la regulación jurídica buscando convivir en un mundo acelerado...

Es difícil imaginar grafiteros o actos vandálicos de sábado-noche en Jirueque. Tampoco problemas por esquivar cacas de perros en los parques, ni vehículos mal aparcados bloqueando pasos de peatones... 
Tampoco parecen probables demasiados choques xenófobos entre los 80 vecinos de siempre...

«No importa, hay otras cuestiones», nos explica Virgilio. «Aquí tenemos máquinas cosechadoras y éstas transitaban por las vías públicas molestando a los demás. La convivencia no es fácil nunca y vivir en armonía es imprescindible siendo pocos o muchos.

También se vertían escombros en el campo de forma indiscriminada. No es agradable pasear y ver los residuos del vecino.

Así que alguien trajo aquí un día el texto de esta Ordenanza, lo leímos, lo pensamos, se votó y por el momento funciona.»

Y es indudable, que Virgilio tiene razón, pero lo más importante es como argumenta el auténtico sentido y por qué de la Ordenanza:

«Con un quórum record de 76 vecinos, adoptamos mayorías absolutas con 50 o 60 personas, siendo por tanto enormemente democrático. Todos opinamos» sigue explicando Virgilio, «nadie sale de aquí sin ser escuchado. Y para que funcione procuramos predicar y dar medios.»

«Prohibimos entrar las cosechadoras por las calles, pero les hemos hecho caminos para que pasen sin que molesten y que además nos sirven de cinturón.»

La Ordenanza de Convivencia Ciudadana de Jirueque, con 24 artículos es sencilla y breve.

Su articulado contiene cuestiones tal vez más básicas que lo habitual en este tipo de normas. No hace falta tipificar de forma exahustiva, pues aquí la coactividad y /o posible eficacia de la norma no vendrá dada por la tramitación del expediente e imposición de la sanción, sino por la concienciación social, por el sentimiento colectivo de obligatoriedad....

Nos encontraremos pues, con conceptos cuya indeterminación platearía en otros supuestos problemas jurídicos prácticos de aplicación, pero que en este caso, el descender al detalle convertiría a la norma en inútil.

Así por ejemplo el artículo 4 exige que se observe «el debido civismo y compostura, no alterando el orden ni la tranquilidad pública con escándalos, riñas $y$ tumultos».

También se regulan las cuestiones sobre cuidado de bienes públicos, animales domésticos, relaciones de vecindad, medio ambiente...

A continuación se anexa tabla resumen sobre las principales materias reguladas por las ordenanzas vigentes. 
MUNICIPIO Y CIVISMO. LAS ORDENANZAS MUNICIPALES COMO INSTRUMENTO PARA LA...

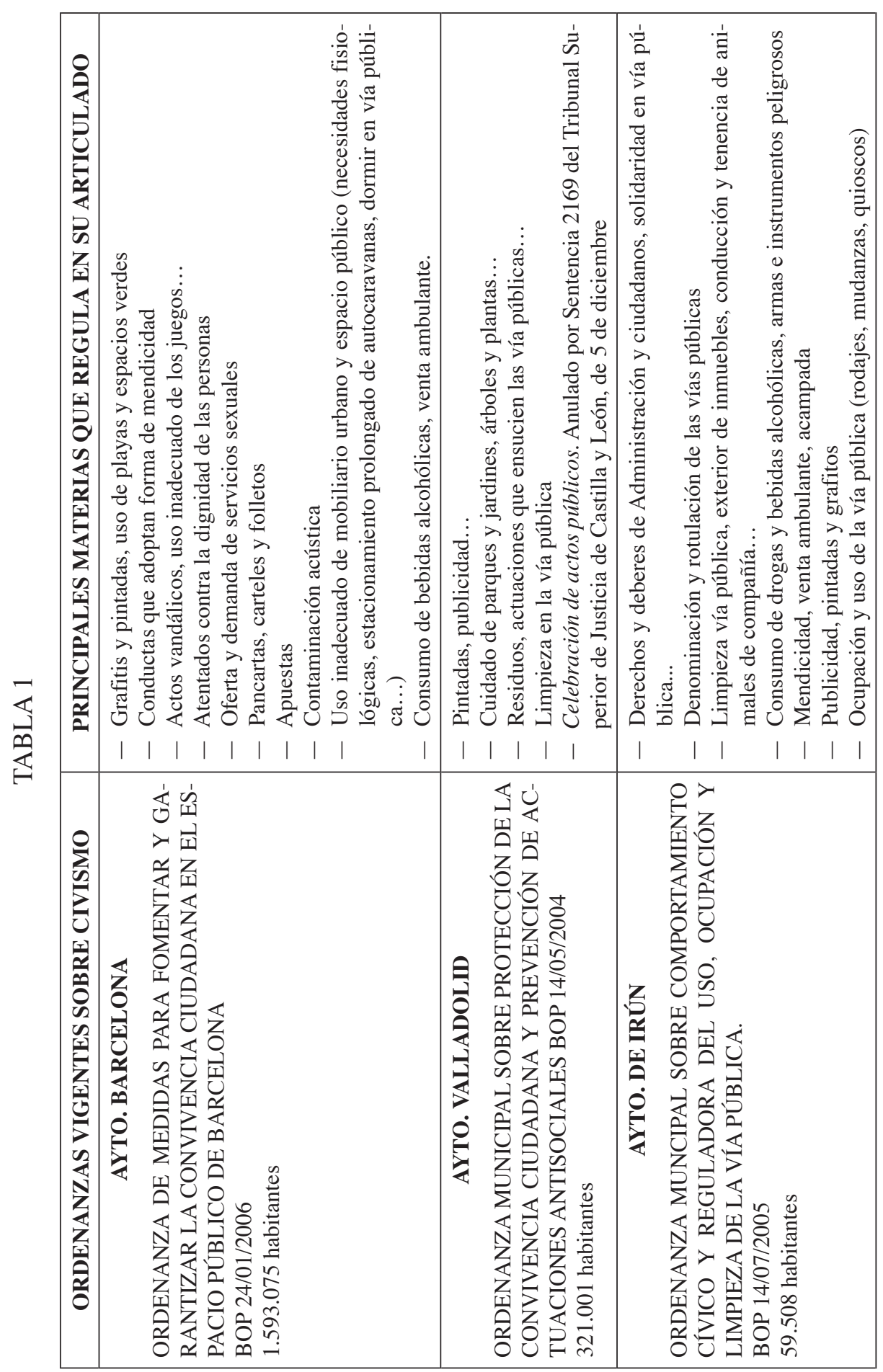


REALA 307 (MAYO-AGOSTO, 2008)

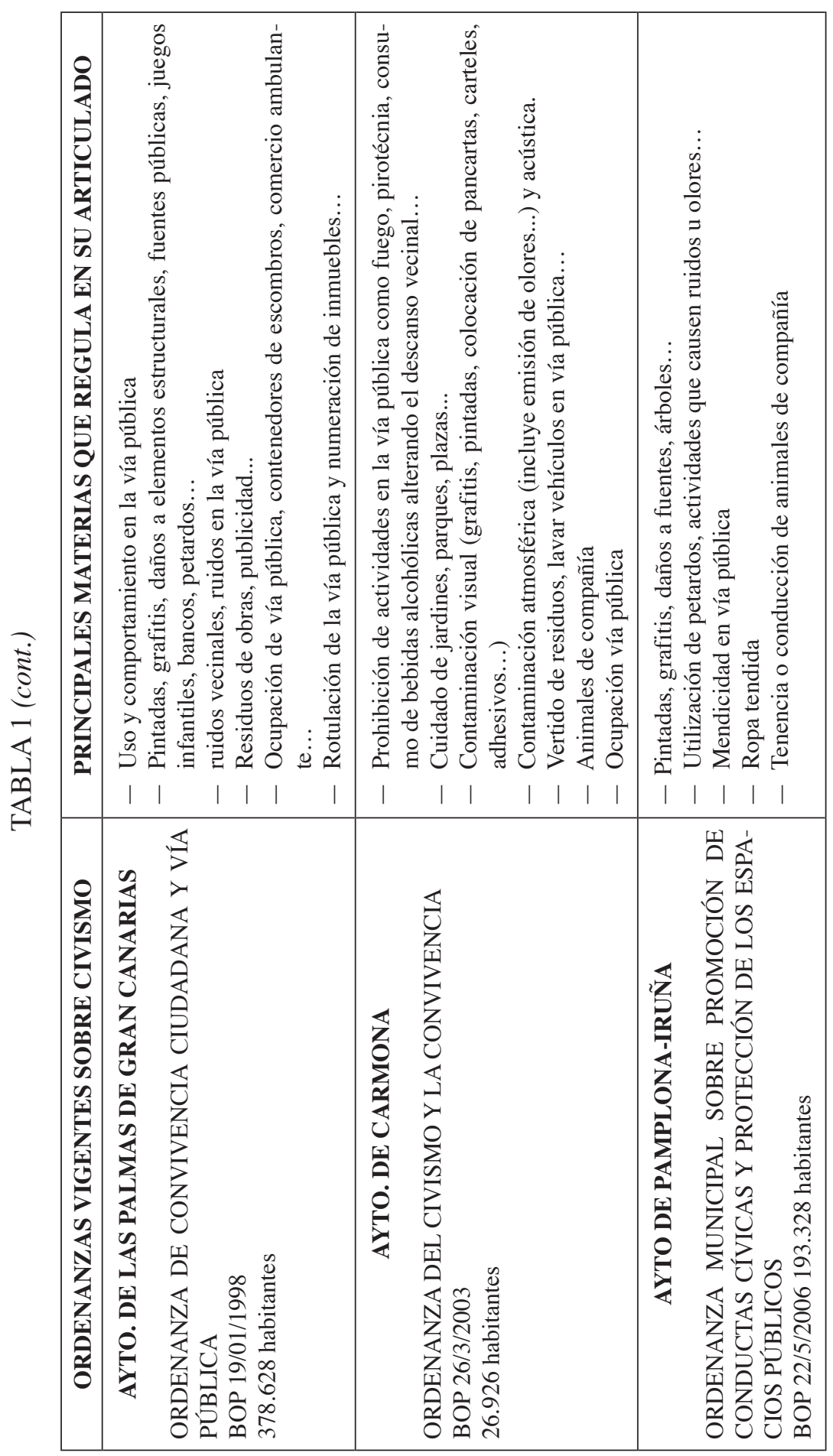


MUNICIPIO Y CIVISMO. LAS ORDENANZAS MUNICIPALES COMO INSTRUMENTO PARA LA...

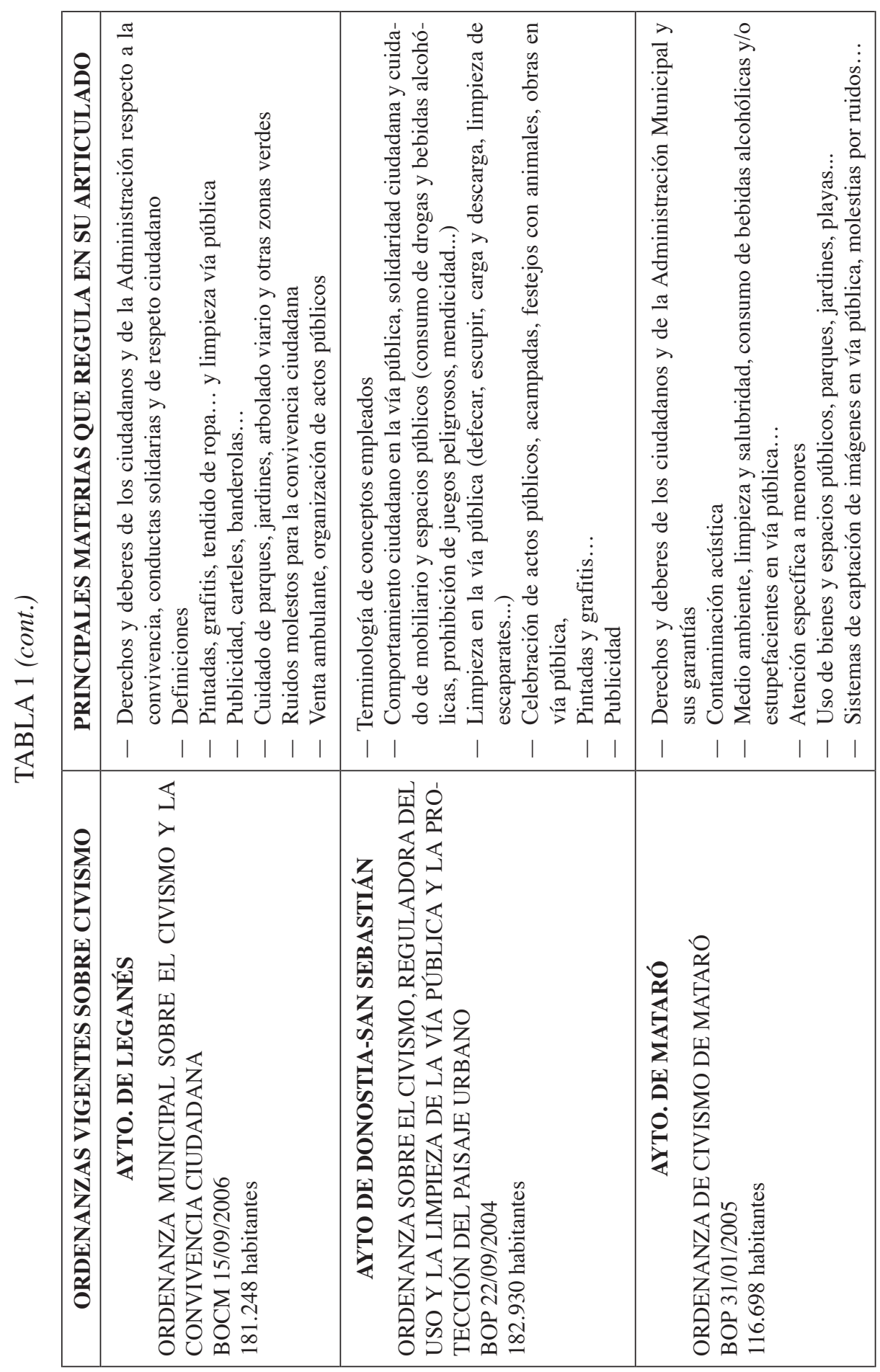




\section{LA SANCIÓN ADMINISTRATIVA COMO MEDIO DE SENSIBILIZACIÓN PARA CONDUCTAS CÍVICAS}

\section{La potestad sancionadora local tras la Ley 57/2003, de 26 de diciembre, de medidas para la modernización del gobierno local}

La Ley 57/2003, de 26 de diciembre, de Medidas para la Modernización del Gobierno Local, aborda el problema que al ejercicio de la potestad sancionadora local suponía la insalvable exigencia de encontrar un a ley sectorial que hiciera viable el ejercicio de esa potestad, tal y como expone en su preámbulo.

Esta intención se consigue con la introducción a través del artículo 1.4 de la ley 57/2003 del título XI en el texto de la Ley 7/985, Reguladora de las Bases del Régimen Local (artículos 139 a 141) »Tipificación de las infracciones y sanciones por las Entidades Locales en determinadas materias», y con la modificación según el artículo tercero de la Ley 57/2003 de los artículos 127.1 y 129.1 de la Ley 30/1992.

El artículo 140 impondrá a la Ordenanza local el establecimiento preciso de la triple clasificación de las infracciones en muy graves, graves y leves, siguiendo así el principio contenido en el artículo 129. de la Ley 30/992.

El criterio que se sigue para que la regulación local tipifique adecuadamente las infracciones atiende, de una parte, a la conveniencia del interés local (por ello excluye las conductas subsumibles en la Ley 1/1992, de 21 de febrero de Protección de la Seguridad Ciudadana) al normal uso y prestación de los servicios públicos así como de equipamientos e infraestructuras $\mathrm{y}$, finalmente, al dominio público local.

El artículo 141 impone topes máximos cuantitativos a las multas que pueden imponer los Entes Locales, en función de la clase de infracción según su gravedad, estableciendo para las muy graves el límite de 3.000 euros, límite que no puede rebasar la Ordenanza Local salvo que una Ley permita, de forma expresa, la superación de aquellos.

Ante esta nueva regulación, debemos reparar al menos en tres cuestiones importantes:

Primero: al no fijar un límite máximo en los tramos de las cuantías de las sanciones, pueden producirse importantes y distorsionadoras diferencias en las cuantías de las sanciones previstas para una misma infracción en municipios distintos.

Segundo: que tampoco se incluye la obligación de reparación y restauración de los bienes afectados de forma acumulativa a las sanciones que pudieran corresponder. 
$Y$ tercero: No se establece otro tipo de medidas distintas a la sanción pecuniaria, como por ejemplo, la posible clausura temporal de la actividad, la suspensión de licencia o autorización, la prohibición de uso o acceso a bienes e instalaciones municipales...

Sobre los titulares de la potestad sancionadora, la Ley 57/2003, repite las competencias del Alcalde para imponer sanciones, aunque permite que sea delegable (artículo 21.3).

La potestad normativa se atribuye al Pleno, ya que es el competente para aprobar las Ordenanzas. No obstante, tanto la aprobación inicial de las Ordenanzas como el ejercicio de la potestad sancionadora corresponden a la Junta de Gobierno (en los Municipios que tengan ese órgano).

\section{Sanción administrativa y principio reeducador o concienciador}

Las Ordenanzas Municipales sobre civismo, que decidan darse los Municipios españoles, deben tener como finalidad preservar el espacio público como ámbito de convivencia y civismo, donde todos tengan derecho a desarrollar en libertad sus actividades de ocio, esparcimiento, con respeto a los derechos de los demás y a los deberes de solidaridad, respeto mútuo y tolerancia, y no quedarse en respuestas parciales o de choque contra problemas concretos como puede ser el «botellón», el vandalismo contra mobiliario urbano...

Pero como hemos tenido ocasión de comprobar en las experiencias descritas en el epígrafe anterior, un texto normativo integrador, además de definir las conductas antisociales que deterioran y degradan la ciudad, debe buscar alternativas a la pura sanción coactiva y represora que se traduce en la mayoría de los casos en sanción pecuniaria.

Así lo exige, además, la aplicación de los principios penales de reeducación y resocialización del derecho penal.

Afortunadamente, ya no son una anécdota las medidas que la Fiscalía adopta a la hora de sancionar, fundamentalmente a menores, orientadas a la reeducación. Recordemos la sanción impuesta hace algunos años a un delincuente juvenil reincidente y analfabeto a «aprender a leer»; o la limpieza de grafitis a los autores de actos vandálicos, las tareas de ayuda en centros sociales...

Y es que podemos imaginar el escaso resultado que una sanción administrativa de multa puede tener como medida disuasoria frente a un menor que destroza papeleras, que ensucia de grafiti una fachada, ...se generará un expediente, acabará en un recibo y responderán sus padres o tutores.

Padres o tutores que, en casi el 99\% de los casos agradecería que la «gracia» de su chaval, conllevara cuando no un madrugón para colaborar en la limpieza de los muros con el chorro de arena, o mantenerse sentadito y atento a explicaciones sobre reciclaje... y no proceder al desembolso económico para solucionar el asunto. 
Que la respuesta administrativa no puede quedarse en la mera sanción económica, es una necesidad que al menos la mayor parte de los Municipios ${ }^{7}$, como hemos podido comprobar, han querido plasmar en sus nuevas normas.

No obstante, determinar cuales son las medidas alternativas a la sanción más adecuadas y efectivas, va ser una tarea casi tan difícil como articular los mecanismos precisos para llevarlas a la práctica.

Por ello, debemos ser realistas e intentar no caer en lo que está siendo el gran enemigo de las estas normas administrativas: la demagogia.

En la mayoría de los casos no tiene desarrollo alguno, de tal forma que resulta del todo imposible aplicarlos. Se redacta una «pomposa» exposición de motivos, incluso a veces se acompaña de una campaña de marketing importante, llenando de banderolas y carteles las marquesinas de la ciudad, pero luego no se aplica.

Es frecuente olvidar lo complejo que resulta la tramitación de un expediente administrativo sancionador para una Administración Local y mucho más complicado todavía va a ser sustituir la sanción pecuniaria por medidas resocializadoras.

El respeto a los principios del Derecho Penal, exige una serie de garantías difíciles de articular en los Municipios españoles tan carentes de medios.

Sirva de ejemplo el importante esfuerzo que llevó a cabo el Ayuntamiento de Carmona con su Ordenanza sobre civismo, y en el que apenas se tramitan dos o tres expedientes anuales y nunca se han puesto en práctica las medidas alternativas previstas en su artículo 82 .

Si realmente pretendemos aplicar medidas que logren la reeducación y consigan concienciar a los infractores con el fin de evitar la comisión de nuevos ilícitos, debemos ir más allá de la simple sanción económica y considerar la Ordenanza y sus sanciones como una herramienta más para garantizar la convivencia en el espacio urbano.

Ese ha sido el planteamiento del Ayuntamiento de Barcelona.

Articulada como una pieza más de todo el conjunto de actividades y actuaciones llevadas a cabo por el Ayuntamiento, la sanción se instrumenta como la última de las respuestas al conflicto y reacción al incumplimiento o lesión del bien jurídico.

Se dedican veintisiete artículos al régimen sancionador. Se prevé la redacción de un manual operativo sobre la aplicación de la Ordenanza.

La creación de una unidad administrativa encargada de los procedimientos a que de lugar, la figura de los agentes cívicos (art. 77) para vigilar y ayudar al

7 Salvo la Ordenanza de las Palmas de Gran Canaria que data de 1998 y está pendiente de revisión en ese sentido. 
cumplimiento efectivo y la sustitución de las multas y reparación de los daños por trabajos en beneficio de la comunidad.

Así en su artículo 93 establece la posibilidad de ...«sustituir la sanción de multa por sesiones formativas, participación en actividades cívicas u otro tipo de trabajos para la comunidad...»

Esta posibilidad de sustitución de la sanción pecuniaria por medidas formativas, trabajos para la comunidad o cualquier otro tipo de actividad de carácter cívico, encuentra un régimen específico en los menores de edad, que atiende fundamentalmente al respeto de sus derechos y búsqueda de su reeducación (artículo 84).

Otro referente, que dado el tiempo transcurrido desde su aprobación ya ha podido ponerse en práctica, es el planteamiento del Ayuntamiento de Mataró, que en su artículo 29 establece la posibilidad de realizar actividades alternativas a la sanción económica.

Con ciertos condicionamientos en cuanto al tipo de infracción (leve, sin reincidencia...) se permite la posibilidad de conmutar la sanción por prestaciones sustitutivas.

Su concreto desarrollo se efectúa a través de un «catálogo de medidas alternativas/conmutadoras de la sanción económica», reguladas según una Instrucción general del sistema de prestación sustitutiva, aprobado mediante Decreto de Alcaldía.

Así frente a propuestas cuando menos «utópicas» previstas en otras Ordenanzas, en las que el infractor solicita la medida cuando quiere y propone lo que está dispuesto a hacer, aquí existen unas pautas y procedimiento para ello.

Y también el municipio de Leganés, ha apostado por la sustitución de la sanción pecuniaria en todos los supuestos posibles y articula un sistema de «Terminación convencional y trabajos voluntarios alternativos a las sanciones».

La Resolución de 6 de noviembre de 2006 por la que se aprueba el Programa de Medidas Alternativas a la Sanción para la Reeducación Cívica « de acuerdo a los principios orientadores del civismo y la reeducación que inspiran la Ordenanza sobre el Civismo y la Convivencia Ciudadana del Ayuntamiento de Leganés, se prevé la posibilidad de que en algunos supuestos la sanción económica sea sustituida o conmutada en parte por alternativas orientadas a la reparación, reeducación y sensibilización».

El programa, desarrolla lo dispuesto en el título VI de la Ordenanza, y así determina el ámbito de aplicación, las entidades colaboradoras para los programas de trabajo, los convenios de colaboración... y el concreto procedimiento de aplicación. 


\section{Otras actuaciones y medidas posibles en la instrucción del procedimiento administrativo}

Pero si como decíamos en el epígrafe anterior, el éxito de cualquier medida que pretenda ser reparadora debe orientarse a la reeducación para lograr concienciar al infractor a reorientar la conducta, veremos como existen otros mecanismos posibles que pueden articularse en base a la aplicación de una buena Ordenanza de Civismo.

La previsión de la posibilidad de adopción de medidas cautelares, de suspensión de autorizaciones, decomiso de los objetos utilizados en la comisión de la infracción, ... no son las únicas posibilidades de reacción.

A veces una denuncia de la Policía Local por una «gamberrada» supone un vehículo para detectar problemáticas que requieren una respuesta. Así puede verse si se trata de menores, si es en horario escolar, si las compañías son «adecuadas», si los padres o tutores responden o se encuentra en situación de abandono, si ha consumido alguna «sustancia»...

La visión que a veces se pretende dar a las Ordenanzas como instrumentos represores, choca con la tarea que desde muchos municipios se realiza de atención a problemas en base a esas llamadas de atención.

Así es frecuente, que una denuncia de lugar a la actuación inmediata de los Servicios Sociales, al apoyo psicológico a menores y padres, orientación escolar...

Aquí es determinante la colaboración entre los diferentes departamentos administrativos (policía-responsables de bases de datos-servicios sociales-educación... incluso urbanismo) y entre las distintas Administraciones Públicas.

Ante estas premisas, algunas Ordenanzas establecen mecanismos específicos fundamentalmente en el caso de menores.

Municipios como el de Leganés, condicionan el inicio de cualquier expediente sancionador a menores de edad, en base a la Ordenanza sobre Civismo y Convivencia Ciudadana (art. 48) a un preceptivo informe emitido por los Servicios Sociales, en donde se constate si existe expediente abierto sobre esa persona, así como sus circunstancias. En casi la totalidad de los casos se procede a una previa entrevista con el menor y sus padres y tutores, tras la cual se emite informe cuyas conclusiones serán determinantes en cuanto a determinar la posibilidad de iniciar el correspondiente procedimiento sancionador.

Barcelona prevé medidas muy similares, regulando la mediación en el caso de menores, atendiendo de forma específica el tema de la prostitución desde una perspectiva social integradora... y destinando el importe de las sanciones pecuniarias a actuaciones para el fomento del civismo.

A continuación se anexa tabla resumen de medidas sancionadoras. 
MUNICIPIO Y CIVISMO. LAS ORDENANZAS MUNICIPALES COMO INSTRUMENTO PARA LA...

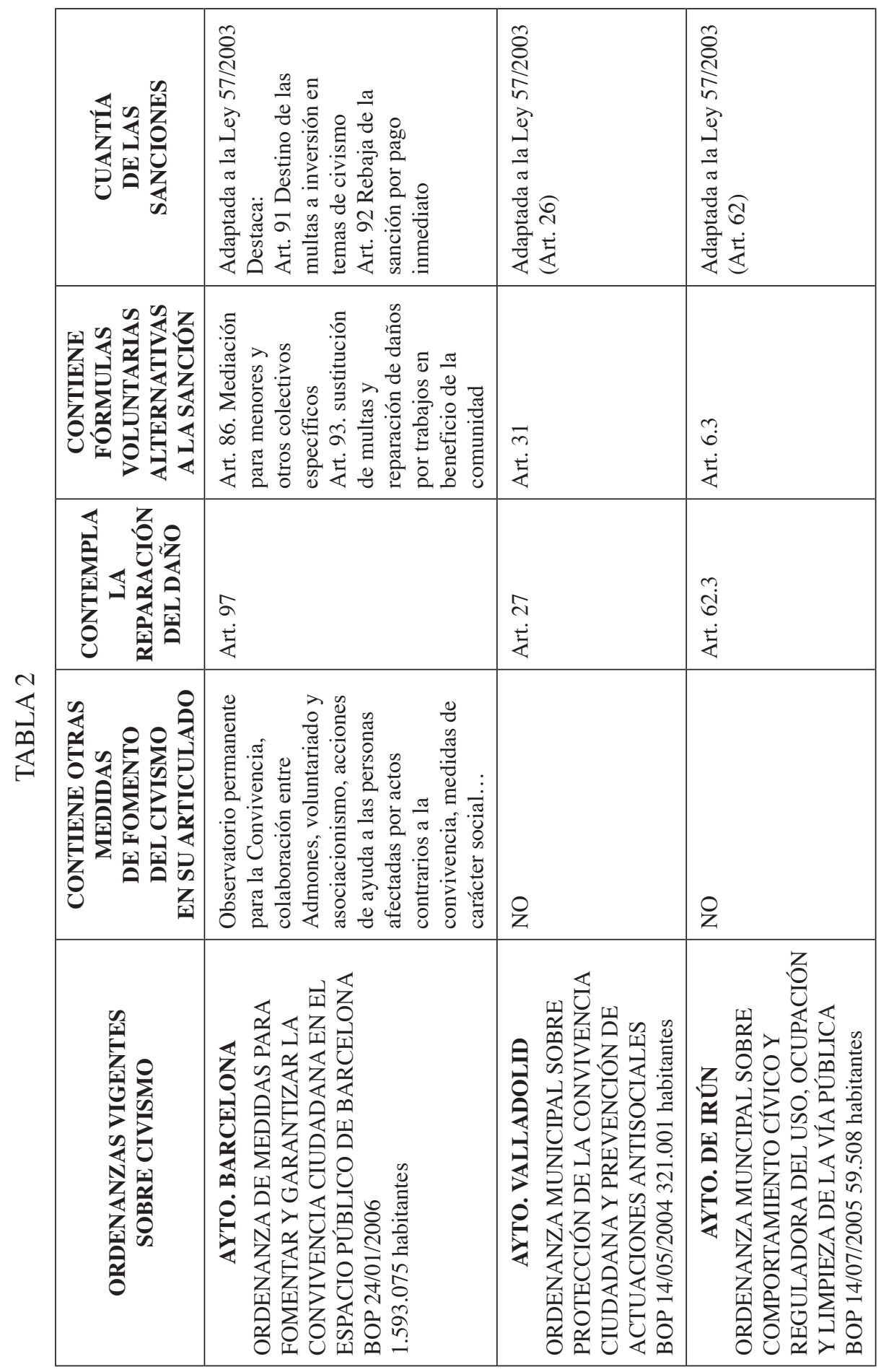


REALA 307 (MAYO-AGOSTO, 2008)

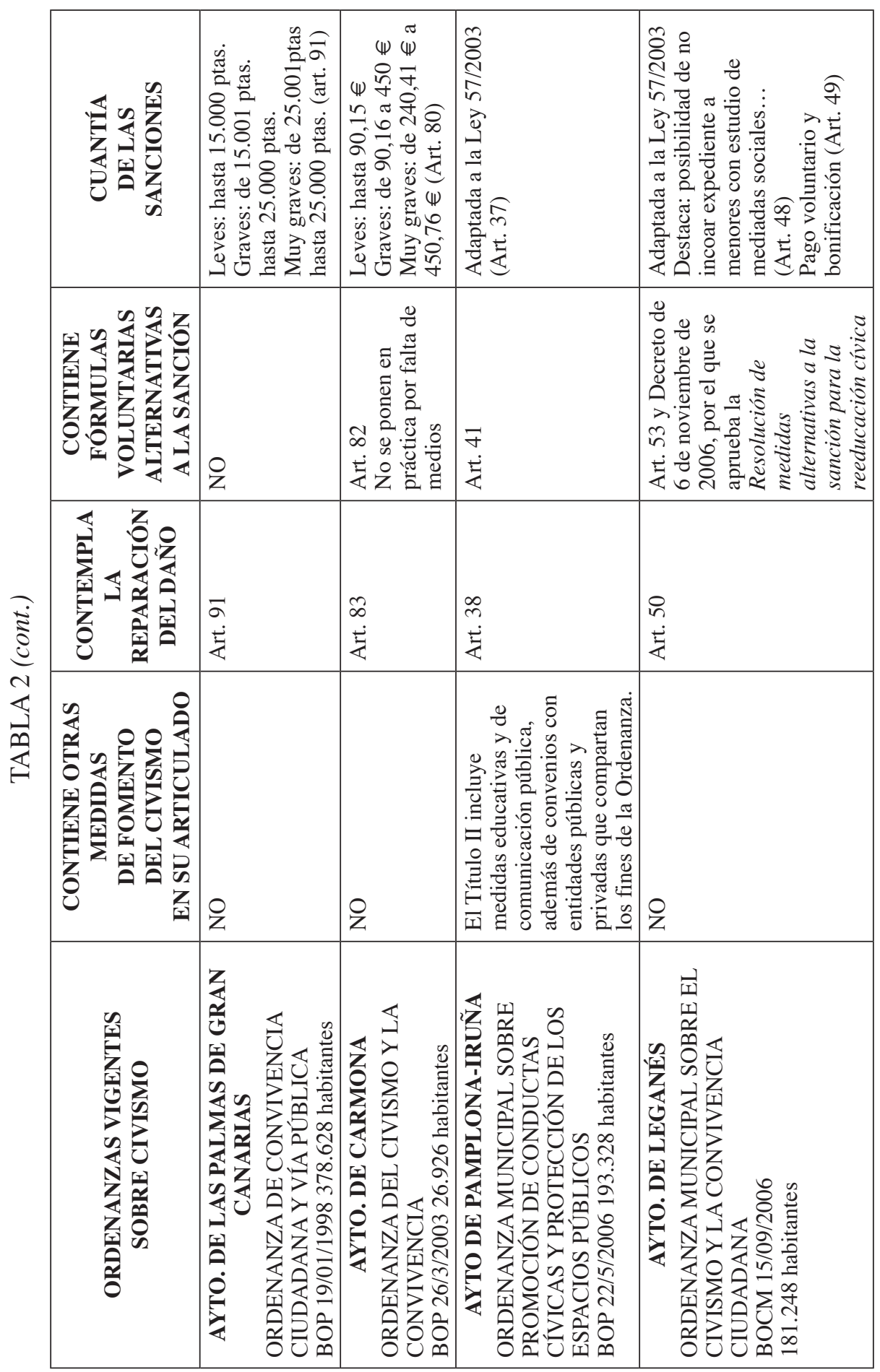


MUNICIPIO Y CIVISMO. LAS ORDENANZAS MUNICIPALES COMO INSTRUMENTO PARA LA...

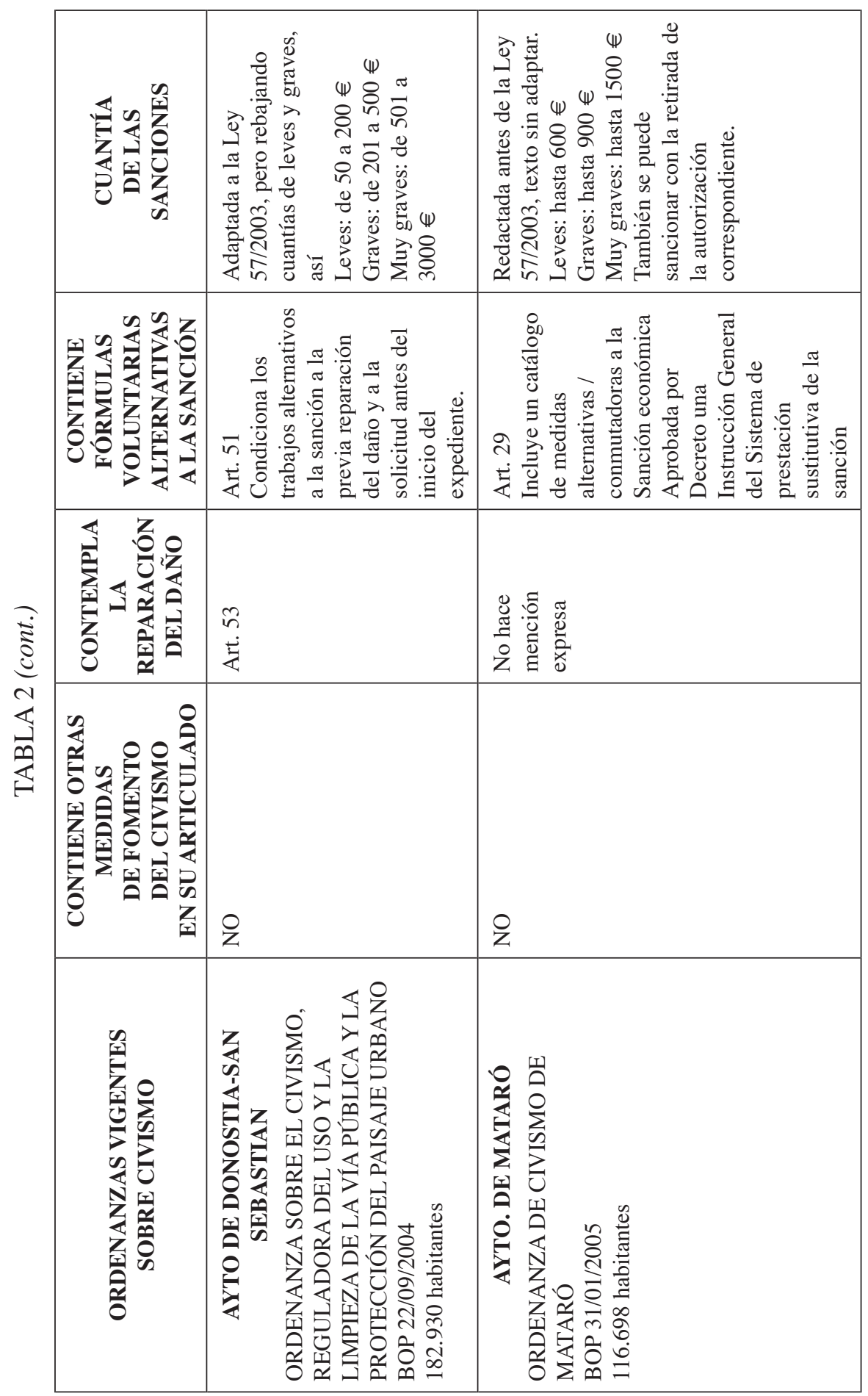




\section{CONCLUSIONES}

En el presente estudio hemos podido comprobar la importancia y el auténtico significado o extensión del término convivencia en el ámbito del municipio y de cómo ha evolucionado recientemente el marco normativo, fundamentalmente con la nueva Ley 57/2003, de 16 de diciembre, de Medidas para la Modernización del Gobierno Local, habilitando a los Municipios y dejándo cada vez más en su mano la regulación.

La Administración Local, ha decidido encarar el asunto llevando a cabo diversas propuestas y actuaciones, pero dando un protagonismo a las nuevas Ordenanzas sobre civismo, que según como se articule puede resultar peligroso.

Porque hoy la gestión municipal va a encontrarse con el gran reto de la diversidad y la convivencia y su tratamiento necesariamente estará condicionado a la articulación de la diferencia, de forma que ser cívico exija también ser tolerante y esa diferencia deje de ser fuente de conflicto y se convierta en valores añadidos a nuestros municipios.

El análisis de las recientes Ordenanzas Municipales sobre civismo en los municipios españoles, nos lleva a consideraciones importantes y preocupantes:

Primero: La dificultad de lograr aprobar esas ordenanzas y que cuenten con el respaldo de la ciudadanía.

Los casos de Sevilla y Santander, que hemos tenido ocasión de analizar, no son los únicos que tienen dificultades para su aprobación definitiva, por ejemplo Zaragoza, se encuentra en una situación similar, y la Ordenanza de Valladolid ha sido anulada parcialmente.

Porque el consenso, tanto político y social es aquí imprescindible para acometer cualquier medida que pretenda proporcionar soluciones al difícil equilibrio entre derechos y deberes y la dificultad de aceptar que la libertad de uno mismo, es el limite de la libertad del otro.

La Ordenanza debe ser una responsabilidad conjunta ciudadanos-Administración Local.

Sólo se revelan válidas actuaciones basadas en el esfuerzo de que la información ciudadana, la educación y las oportunidades vayan generando nuevas actitudes participativas de la población.

Y únicamente articuladas en ese marco del fomento de la participación ciudadana, es donde las Ordenanzas Municipales van a resultar una herramienta tremendamente eficaz para la convivencia en la ciudad. 
Pensemos en que la Ordenanza Municipal, como Derecho Local, debe ser aportada a los Tribunales cuando la invocamos, se entiende que los Jueces no tienen obligación de conocerla, entonces... ¿cómo podemos pretender que los vecinos la respeten y sepan de ella si no es con un enorme esfuerzo de información?

El éxito depende de que se trate de una tarea hecha por y para todos, donde Policía local, técnicos municipales, entidades, políticos... deben ser capaces de coordinarse y trabajar juntos.

Debe servirnos de ejemplo el enorme esfuerzo de Barcelona, que ha convertido la preocupación por el civismo en uno de los pilares de su política municipal, por ello la Ordenanza constituye una pieza más en todo un entramado de actuaciones, en los que el papel del ciudadano es fundamental: se educa, se informa, se apoya y después se pide colaboración y cumplimiento.

Segundo: Sólo serán susceptibles de aplicación práctica, las Ordenanzas concisas (que regulen sólo lo que es preciso regular), realistas (atendiendo al orden socio-cultural y espacial donde deben ser aplicadas) y que se redacten con adecuada técnica jurídica

Sirva de ejemplo el caso del Municipio de Jirueque, con una norma sencilla para un pueblo con problemas y estructura mínimos, pero que responde la reclamación de todo vecino que necesita normas que eviten enconados conflictos personales y los sitúen en un ámbito más objetivo. El éxito de esta norma es la participación y su cumplimiento en base a la concienciación social.

Tercero: Los municipios deben acudir a la sanción pecuniaria y a las medidas represivas en último extremo, buscando fórmulas de reeducación y reinserción, a través también de las posibilidades que hemos visto puede ofrecerles la Ordenanzas, con medidas sustitutivas a la sanción, fundamentalmente educativas, de trabajos voluntarios a la comunidad...

Cuarto: La necesidad de medios para poder llevar a cabo cualquier medida o actuación eficaz desde los Municipios.

No sólo es dotarse de una Ordenanza. Hemos podido comprobar como municipios no llevan a la práctica sus normas por falta de medios.

Se echa de menos un estudio simplemente estadístico de la actividad normativa de los municipios españoles, no existe ni a nivel histórico.

La Federación Española de Municipios, lleva tiempo anunciando la creación de un grupo de trabajo sobre civismo, así como la redacción de una «ordenanza tipo», pero de momento no ha afrontado el tema.

Con este estudio, hemos tratado de explicar en qué consiste ese ansiado civismo urbano, sus beneficios para la libertad y para la democracia y el papel 
fundamental de nuestros municipios en lograr ese compromiso con la ciudad, con los vecinos, con lo público.

Sirva este trabajo para recordarnos que sólo con el ejemplo lograremos inculcar esa forma de vivir.

Abramos cuanto antes un foro de debate y trabajo para conseguir dotar a nuestros Municipios de medios e instrumentos para convertirlos en auténticos referentes de participación y diálogo, de trabajo y defensa por lo que es de todos.

Apoyémonos, también en las Ordenanzas Municipales convirtiéndolas en un instrumento, de todos para la convivencia

Llevemos la esencia del civismo a la Administración más cercana al ciudadano porque solo así conseguiremos transmitirlo.

\section{BIBLIOGRAFÍA}

Alegre Ávila, J.M: Potestad sancionadora y entes locales: el principio de legalidad sancionadora. Revista de Estudios Locales. Febrero 2004.

BeAto EsPejo, M.: El medioambiente urbano y la convivencia ciudadana. El ruido por el consumo de bebidas en la vía pública. Revista de Administración Pública n. ${ }^{\circ} 139$. Centro de Estudios Constitucionales. Enero-abril 1996.

BALleSTEROS FERNÁNDEZ, A. y otros: Comentarios a la ley 57/2003: Título XI tipificación de las infracciones y sanciones por las entidades locales en determinadas materias. El consultor 2004.

Bello PAREDES, S.: La reserva de ley en el ámbito sancionador local, ¿estamos ante el comienzo del fin de una larga disputa? Revista de Estudios de Administración Local 286-287 mayo-diciembre de 2001.

Bello PAREDES, S.: Las ordenanzas locales en el vigente derecho español. Alcance y articulación con la normativa estatal y autonómica. INAP. Universidad de Burgos 2002.

CAmps Cervera, V.: Virtudes públicas. Premio Espasa Mañana de ensayo 1990.

EMBID IRUJO, A.: Ordenanzas y reglamentos municipales en el derecho español. INAP 1978

FERnÁNDEZ MONTALVO, R., magistrado del Tribunal Supremo: La potestad normativa municipal en la Jurisprudencia de 2003.

GARcía MANZANO, P.: La potestad reglamentaria en el proyecto de ley de medidas para la Modernización del Gobierno Local Revista Jurídica de Castilla y León. Febrero 2004, n. ${ }^{\circ} 2$.

GARRIDo HernÁndeZ, I. J.: Comentarios a la Ley 57/2003, de medidas para la modernización del gobierno local (monografías.com).

GINER, S.: Diversidad y democracia en las ciudades: ciudadanía pública. Dentro del libro Diversidad y Convivencia en las ciudades. Ponencias presentadas al seminario Pensando en lo local en un nuevo siglo en la Fundación Carles Pi i Sunyer. CEMCI 2004.

Golding, W.: El señor de las moscas. Alianza 1998. 
HERNÁNDEZ DE MARCO, S.: La configuración de la policía local con funciones administrativas y de convivencia ciudadana. El Consultor, n. 5 marzo 1993.

HERNÁNDEZ LÓPEZ, J.: Sobre la nueva potestad sancionadora municipal a la luz de la de la Ley 57/2000. Revista de estudios Locales. Febrero 2004.

HiJANO PÉREZ, Á.: Las ordenanzas municipales como norma del gobierno local. CEMCI 2004.

IBÁÑEZ DE LA RENTERÍA. Discurso sobre el gobierno municipal, en el libro de M. Baena del Alcazar Estudios de la Administración.

Jerez CALDERón, J.: La potestad reglamentaria local. El Derecho Local en la doctrina del Consejo de Estado. Coordinado por Jerónimo Arozamena Sierra. BOE. Madrid 2002.

LASAgABASTER ERRARTE, I.: Potestad sancionadora local en la Ley 57/2003 de Medidas para la Modernización del Gobierno Local. Revista Vasca de Administración Pública. IVAP n. ${ }^{\circ} 68$ enero-abril 2004.

PARejo Alfonso, L., LobARTo Brime, F.: Las Ordenanzas y Reglamentos de las entidades locales. Revista de Administración Local n. ${ }^{\circ}$ 397, julio-agosto 1988.

PARejo Alfonso, L.: La potestad normativa local. Seminario de Régimen Local. Marcial Pons 1998.

MuÑoz MACHAdO, S. y otros: Tratado sobre Derecho Municipal, TOMO I. Cívitas, 1998.

ORDUÑA PRADA, E.: Ordenanza municipal y potestad sancionadora: la sorprendente concisión de la STC 132/2001, de 8 de junio. Revista de Estudios de Administración Local, 286-287 mayo-diciembre de 2001.

Salanova AlCAlde, R.: La Ley 57/2003, de 16 de diciembre, de Medidas para la Modernización del Gobierno Local: un comentario crítico. Revista Aragonesa de Administración Pública. n. ${ }^{\circ} 24$, junio 2004.

SÁNCHEZ GOYANES, E.: La potestad normativa del municipio español. Publicaciones Abella. Madrid 2000.

Santayana Bustillo, L. DE.: Gobierno político de los pueblos de España y el corregidor, Alcalde y Juez en ellos. Zaragoza.

Valdeavellano, L.G. DE.: Curso de historia de las instituciones españolas Ed. Revista de Occidente, 1973.

YELA M.: Libre desarrollo de la personalidad en un espacio social compartido Libertades personales y convivencia social. Banco de Bilbao. Karpos SA 1980. 

II. Jurisprudencia 
